\title{
Prevalence and molecular identification of Cryptosporidium spp in cattle in Baghdad province, Iraq
}

\author{
H.H. Alseady* and M.H. Kawan \\ * Department of Parasitology, College of Veterinary Medicine, University of Baghdad, Baghdad, Iraq \\ alseadyhaider@gmail.com
}

(Received November 12, 2018; Accepted January 13, 2019)

\begin{abstract}
The objective of this study was to record the prevalence rate of Cryptosporidium and to determine the Cryptosporidium spp in cattle in different parts of Baghdad province. A total number of 100 fecal samples from different age groups were collected. Conventional method using modified Ziehl-Neelsen for staining fecal smears and molecular techniques for detection the prevalence and determines the species of Cryptosporidium that cause infection. The overall prevalence of infection with Cryptosporidium was 21\% (21/100) by conventional method; nested PCR was done that targeting 18S rRNA gene on the same samples in which Cryptosporidium DNA identified in 38 samples (38\%). Four species of Cryptosporidium in cattle were detected for the first time in Baghdad province: C. parvum (6/10), C. andersoni (2/10), C. bovis (1/10) and C. ryanae (1/10). The determination and characterization of Cryptosporidium spp in cattle was very important to avoid the infection to other animals and handlers and for applying control programs.
\end{abstract}

Keywords: Cryptosporidium, Prevalence, Cattle, Nested PCR, Sequences analysis Available online at http://www.vetmedmosul.com

\section{نسبة الاتتشار والتثخيص الجزيئي لطفيلي Cryptosporidium spp في الأبقار في محافظة بغداد، العراق حيار حسين عبيل السعيدي و مي حميد كوان$$
\text { فرع الطفيليات، كلية الطب البيطري، جامعة بغداد، بغداد، العر اق }
$$

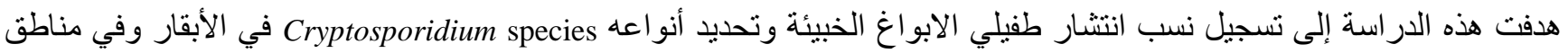

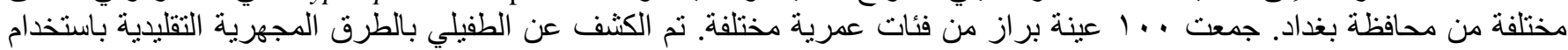

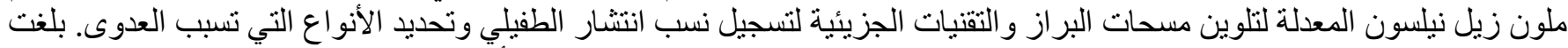

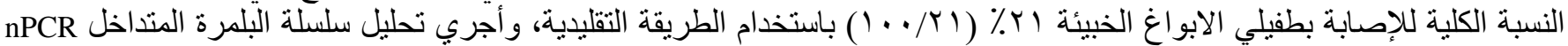

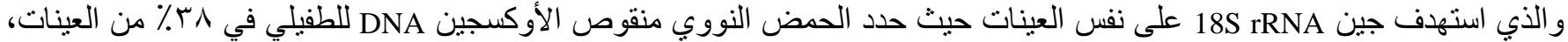

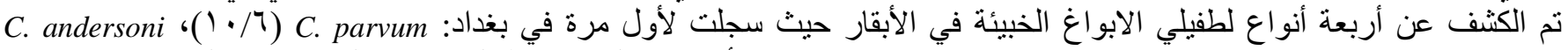

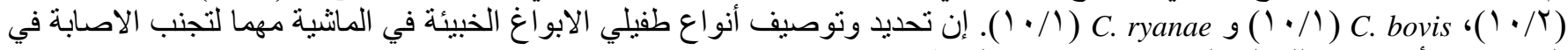
الحيو انات الأخرى وكذلك العاملين واقتر اح بر امج السيطرة.

\section{Introduction}

Cryptosporidium spp. are obligate intracellular (extracytoplasmic) protozoan parasites that can infect a wide range of animals and human hosts worldwide (1). Cattle are considered to be the major zoonotic reservoir for humans (2). Importantly, cryptosporidiosis in cattle causes acute or chronic gastrointestinal disturbance which is recognized as one of the major causes of profuse watery diarrhea, resulting in weight loss and growth retardation, reduced 
milk production, morbidity and, in severe cases, death, leading to considerable economic losses (3). Cryptosporidiosis is transmitted mainly by the fecal-oral route, mostly by food or water contaminated with oocysts, by contact to infected animals or accidentally in laboratories (4). The conventional methods for the diagnosis of infection relies on the microscopic detection of Cryptosporidium oocysts in fecal samples, but these methods are unable to distinguish the different Cryptosporidium spp. based on morphometric or other phenotypic characteristics, due to lack of differentiating morphological features (5). Therefore, the molecular diagnostic techniques based on PCR can detect and identify genotypes. The molecular tools can identify more precise definitions of host-adapted specificity, transmission pathways, and zoonotic possibility of Cryptosporidium spp. (6). Worldwide, cattle are commonly infected with 4 Cryptosporidium spp. which include $C$. parvum, $C$. andersoni $C$. bovis and $C$. ryanae $(1,7)$. Given this diversity of Cryptosporidium species in cattle and differing zoonotic potential, it is important to be able to estimate their prevalence and distribution in particular geographic regions using molecular tools (8).

The objective of this study was to investigate the prevalence of Cryptosporidium infections and determination molecular characterization of Cryptosporidium spp. isolates from different ages of cattle in Baghdad province/Iraq.

\section{Materials and methods}

A total of one hundred fecal samples of cattle were collected from different age groups and both sexes from different parts of Baghdad province, during the period from the beginning of January 2018 to the end of September 2018, fecal smears were prepared from each sample, stained with modified Ziehl-Neelsen staining technique as primary diagnosis of Cryptosporidium oocysts (9).

\section{Molecular diagnosis using Nested PCR (nPCR)}

The nested PCR technique was performed for detection Cryptosporidium spp. based $18 \mathrm{~S}$ ribosomal rRNA gene from cattle fecal samples. This method was carried out according to method described by (10), which included DNA extraction fecal samples by using AccuPrep ${ }^{\circledR}$ stool DNA Extraction Kit, (Bioneer, Korea). Primary PCR master mix preparation by using first primer pair: forward (5-AGACGGTAGGGTATTGGCCT -3) and reverse (5TACGAATGCCCCCAACTGTC-3) (Maxime $^{\mathrm{TM}}$ PCR PreMix Kit ( $i$-Taq)), then placed in PCR Thermocycler (MyGene. Bioneer. Korea). Secondary PCR master mix was prepared by using second primer pair: forward (5ATTGGAGGGCAAGTCTGGTG -3) and reverse (5 TACGAATGCCCCCAACTGTC-3) (Maxime $^{\mathrm{TM}}$ PCR
PreMix Kit (i-Taq)), then placed in PCR Thermocycler (MyGene, Bioneer, Korea).

\section{Sequence analysis}

The genetic analysis done by phylogenetic tree analysis between local Cryptosporidium spp. cattle isolates and NCBI-Blast submission Cryptosporidium species. Then the identification species isolates were submitted into of NCBIGenBank. The DNA sequencing analysis was conducted by using Molecular Evolutionary Genetics Analysis version 6.0 (Mega 6.0) and Multiple sequence alignment analysis of the partial small subunit ribosomal rRNA gene based ClustalW alignment analysis and the evolutionary distances were computed using the Maximum Composite Likelihood method by phylogenetic tree UPGMA method (11).

\section{Statistical analysis}

Statistical analyses were computer assisted using SPSS, variables were assessed by Yat's Chi-square test (12).

\section{Results}

\section{Total infection rate of Cryptosporidium}

Conventional microscopic (modified Ziehl-Neelsen staining) method recorded the overall prevalence rate of Cryptosporidium infection in cattle was $21 \%$ (21/100). On the other hand, molecular (PCR) analysis identified Cryptosporidium spp. infection in 38\% (38/100) (Table 1). All microscopy positive specimens were also found positive by PCR. The prevalence of Cryptosporidium detected by the two methods was significantly different $(\mathrm{P} \leq 0.05)$.

Table 1: Total infection rate of Cryptosporidium infection by conventional microscopic (modified Ziehl-Neelsen staining) method and molecular (Nested PCR) techniques in cattle

\begin{tabular}{cccccc}
\hline Host & $\begin{array}{c}\text { Fecal } \\
\text { samples }\end{array}$ & \multicolumn{2}{c}{$\begin{array}{c}\text { Conventional } \\
\text { microscopy }\end{array}$} & \multicolumn{2}{c}{$\begin{array}{c}\text { Molecular } \\
\text { (Nested PCR) }\end{array}$} \\
\hline \multirow{2}{*}{ Cattle } & $\begin{array}{c}\text { Total No. } \\
\text { examined }\end{array}$ & $\begin{array}{c}\text { No. of } \\
\text { positive }\end{array}$ & $\%$ & $\begin{array}{c}\text { No. of } \\
\text { positive }\end{array}$ & $\%$ \\
\cline { 2 - 6 } & 100 & 21 & $21 \%^{\mathrm{B}}$ & 38 & $38 \%^{\mathrm{A}}$ \\
\hline
\end{tabular}

Variation in large horizontal letters refer to significant differences at a level of $\mathrm{P} \leq 0.05$.

\section{Nested PCR}

Genomic DNA samples obtained from cattle fecal samples were subjected to molecular analysis by nested PCR using 18S rRNA gene specific primers in order to identify the species of Cryptosporidium. Nested PCR of all 100 samples employed in the study exhibited distinct band of $318 \mathrm{bp}$ on agarose gel confirming the presence of Cryptosporidium spp (Figure 1). 


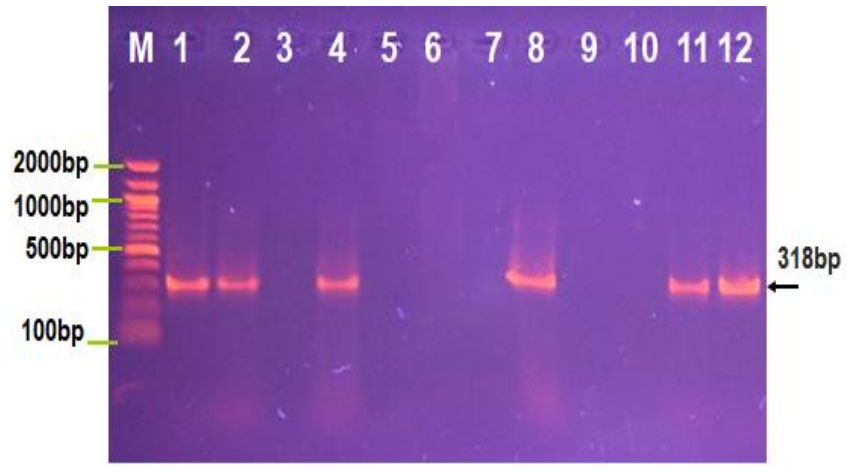

Figure 1: Agarose gel electrophoresis image that show the Nested PCR product analysis of small subunit ribosomal RNA gene in Cryptosporidium spp. from Cattle fecal samples. Where M: Marker 2000-100 bp, lane 1-12 showed some positive Cryptosporidium spp. samples at $318 \mathrm{bp}$ Nested PCR product size.

\section{Cryptosporidium species in cattle}

The entire 10 samples which were positive by nested PCR amplification of 18S rRNA gene of Cryptosporidium were successfully sequenced. The results revealed the presence of four Cryptosporidium spp., namely C. parvum, $C$. andersoni, $C$. bovis and $C$. ryanae, all of them have identity $100 \%$. C. parvum was the most prevalent species being detected in 6/10, followed by $C$. andersoni $2 / 10, C$. bovis and $C$. ryanae had the same infection rate $1 / 10$ of each one (Table 2 and Figure 2).

Table 2: NCBI-BLAST Homology sequence identity between local Cryptosporidium spp. cattle isolates and NCBI BLAST Cryptosporidium spp. Isolates

\begin{tabular}{|c|c|c|c|c|}
\hline \multirow[b]{2}{*}{$\begin{array}{l}\text { Local cattle } \\
\text { Cryptosporidium spp. No. }\end{array}$} & \multirow[b]{2}{*}{$\begin{array}{c}\text { Gen-Bank } \\
\text { accession No. }\end{array}$} & \multicolumn{3}{|c|}{ NCBI BLAST Homology sequence identity } \\
\hline & & $\begin{array}{c}\text { NCBI BLAST } \\
\text { Cryptosporidium spp. }\end{array}$ & $\begin{array}{c}\text { Gen-Bank accession } \\
\text { No. }\end{array}$ & Identity $(\%)$ \\
\hline 1 & MH885559 & C. parvum $^{\mathrm{a}}$ & MH341586.1 & $100 \%$ \\
\hline 2 & MH885560 & C. ryanae ${ }^{\mathrm{c}}$ & MF671873.1 & $100 \%$ \\
\hline 3 & MH885561 & C. parvum ${ }^{\mathrm{a}}$ & MH341586.1 & $100 \%$ \\
\hline 4 & MH885562 & C. parvum ${ }^{\mathrm{a}}$ & MH341586.1 & $100 \%$ \\
\hline 5 & MH885563 & C. andersoni $i^{\text {b }}$ & KX710086.1 & $100 \%$ \\
\hline 6 & MH885564 & C. parvum $^{\mathrm{a}}$ & MH341586.1 & $100 \%$ \\
\hline 7 & MH885565 & C. bovis $^{\mathrm{c}}$ & КС618591.1 & $100 \%$ \\
\hline 8 & MH885566 & C. andersoni ${ }^{\mathrm{b}}$ & KX710086.1 & $100 \%$ \\
\hline 9 & MH885567 & C. parvum $^{\mathrm{a}}$ & MH341586.1 & $100 \%$ \\
\hline 10 & MH885568 & C. parvum $^{\mathrm{a}}$ & MH341586.1 & $100 \%$ \\
\hline
\end{tabular}

Variation in small vertical letters refers to significant differences at a level of $\mathrm{P} \leq 0.05$.

\section{Discussion}

The current study determines the prevalence and genotyping of Cryptosporidium spp. among cattle in different regions of Baghdad province. Fecal samples collected from cattle were screened by microscopy using modified Ziehl-Neelson staining technique and nested PCR. Although microscopy is cheaper to perform and only method to indicates active infection, higher prevalence of Cryptosporidium was recorded by the PCR in this study. The superior sensitivity of PCR in detecting Cryptosporidium infection has been shown earlier clinical trial and in patients from Northern India and South Africa $(13,14)$

The overall prevalence of bovine cryptosporidiosis in cattle in this study was $38 \%$. This finding was comparable with the results of Benhouda et al. (15) whom recorded infection rate $40 \%$ in young calves in Algeria and the $35.5 \%$ were recorded in diarrheic calves in Sudan (16).
However, the prevalence was higher than the $14.4 \%$ infection prevalence reported from dairy farms in the Qinghai-Tibetan Plateau Area in China (7), 17.0\% reported from cattle tested in Poland (17) and $18.6 \%$ in cattle in Ethiopia (18). On the other hand, the infection rate was lower than the $42.85 \%$ reported in calves in Kut city (19), $47.68 \%$ in pre-weaned dairy calves in Northeastern China (3) and $52.2 \%$ in neonatal calves in Algeria (20). The differences of infection ratios could be attributed to the differences in management systems, methods of rearing, age and breed of cattle, environmental conditions, the sampling method and sample size, as well as diagnostic techniques employed in different study localities.

The results of the current molecular study showed the presence of four major Cryptosporidium spp. in cattle. The most prevalent species in pre and post-weaned calves was $C$. parvum, followed by $C$. andersoni, $C$. bovis and $C$. ryanae. Our results are in agreement with the results that recorded by Silverlas (21) in Swedish cattle (22) in Indian 
dairy calves, in calves in northeast China by Zhang et al (3), in Poland (17), in farm animals in Egypt (23), calves in Sudan (16) and in dairy cattle in northeast China (24) all of them recoded the four species of Cryptosporidium. On the other hand, only three species $C$. andersoni, $C$. bovis and $C$. ryanae were detected in the post-weaned calves, these results recorded in Malaysia by Muhid et al. (25) and in north-western China Qi et al. (26), while Silva et al; Shrestha $(27,28)$ identified three Cryptosporidium spp. of cattle, $C$. parvum, $C$. bovis and $C$. andersoni. In Mumbai region of India Hingole et al. (29) and in China Cai et al. (30) were detected three Cryptosporidium species also, $C$. parvum, C. bovis and C. ryanae in pre-weaned dairy calves. Yap et al. (11) detected only two species of Cryptosporidium: C. ryanae and $C$. bovis in cattle in Malaysia also Inpankaew et al. (31) detected two species of Cryptosporidium, C. parvum and C. bovis in dairy cows in Thailand.

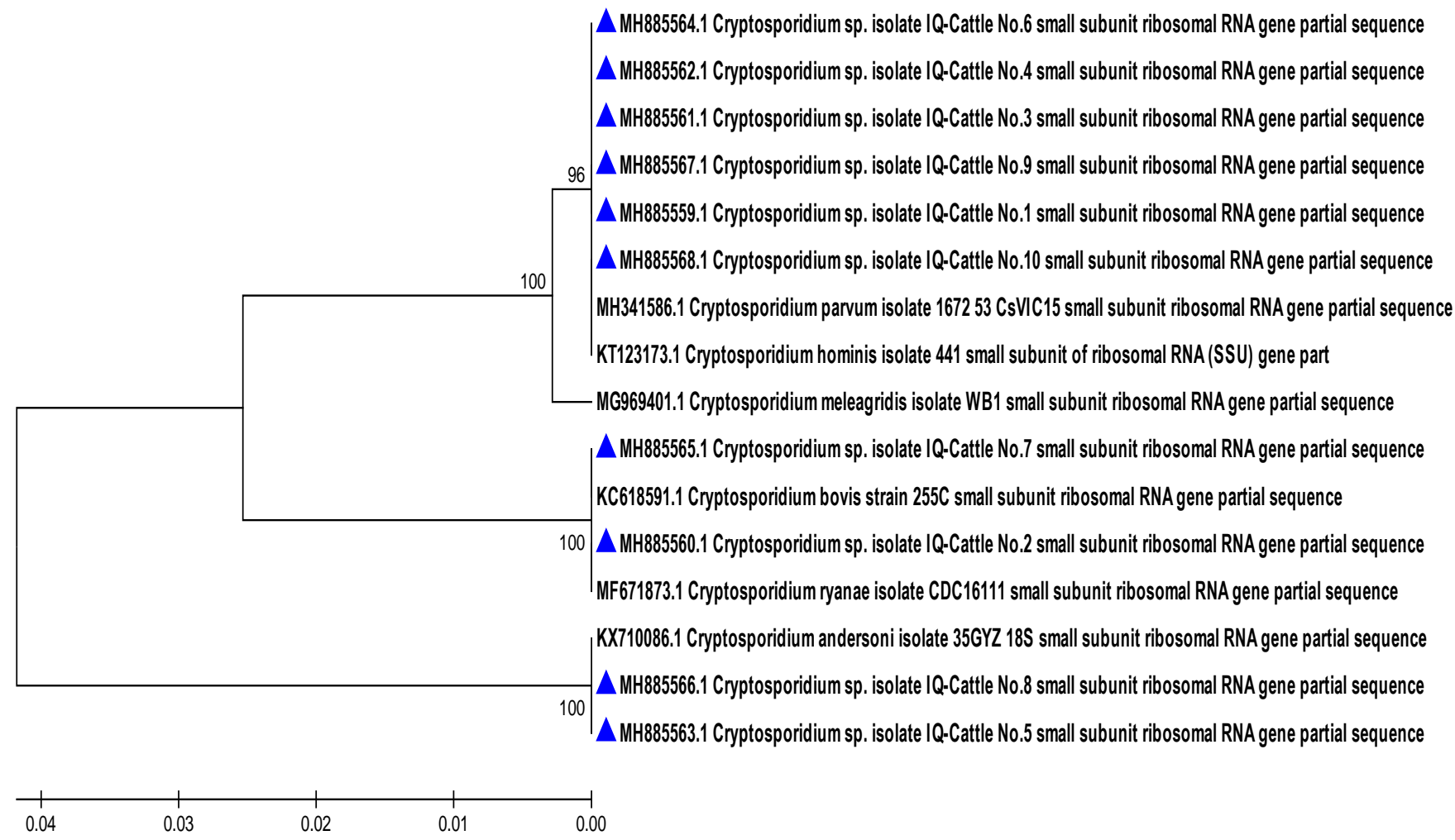

Figure 2: Phylogenetic tree analysis based on the partial sequence Small subunite rRNA gene in local Cryptosporidium spp. cattle isolates that used for Cryptosporidium spp. genetic identification analysis. The evolutionary distances were computed using the Maximum Composite Likelihood method by phylogenetic tree UPGMA (MEGA 6.0 version). The local Cryptosporidium spp. cattle isolates of No. 1, 3, 4, 6, 9 and 10 were showed closed related to NCBI-Blast Cryptosporidium parvum isolate (MH341586.1), The local Cryptosporidium spp. cattle isolates of No. 2 was showed closed related to NCBIBlast Cryptosporidium ryanae isolate (MF671873.1), The local Cryptosporidium spp. cattle isolates of No. 5 and No.8 were showed closed related to NCBI-Blast Cryptosporidium andersoni isolate (KX710086.1), and the local Cryptosporidium spp. cattle isolates of no. 7 was showed closed related to NCBI-Blast Cryptosporidium bovis isolate (KC618591.1) at total genetic change $(0.01-0.04 \%)$.

The species and genotypes of Cryptosporidium infecting cattle are known to vary according to the host age and geographical distribution (32). Given that this study focused more on calves aged <1 month to 6 months old, our study has included cattle with a broader age range $<6$ months to 3 years of age sampled from different regions of Baghdad province to provide a broader picture of
Cryptosporidium infections in cattle in Iraq. C. andersoni, $C$. bovis and $C$. ryanae are truly less pathogenic than $C$. parvum, resulting in low grade infection and lower oocyst output, which in turn reduce the infection pressure among infected animals (33). Our results are in agreement with many studies performed in other countries reported by Taha et al; Helmy; Thomson; $\mathrm{Ng}(33,34-35)$ and thus confirm a 
similar age dependent pattern of infection for Sudan for the first time. C. andersoni infection usually occurs in older calves and adult cattle (16).

This study described the diversity of Cryptosporidium in cattle of all ages in Baghdad province / Iraq. Four species of Cryptosporidium were detected in this study; C. parvum, C. bovis, C. ryanae and C. andersoni. Cryptosporidium infection due to $C$. parvum and $C$. andersoni was more prevalent in cattle in the study area.

\section{Acknowledgment}

The authors gratefully acknowledge Dr. Hassan Hachim for kindly providing the PCR kits and technique and sequence analysis used in the study. We also thank the cattle owners for cooperating and their help in collecting fecal samples in this study.

\section{References}

1. Ryan U, Fayer R, Xiao L. Cryptosporidium spp. in humans and animals: current understanding and research needs. Parasitol. 2014;141:1667-1685.

2. Chalmers RM, Katzer F. Looking for Cryptosporidium: the application of advances in detection and diagnosis. Trends Parasitol. 2013;29: 237-251.

3. Zhang W, Wang R, Yang F, Zhang L, Cao J, Zhang X, Ling H, Liu A, Shen Y. Distribution and genetic characterizations of Cryptosporidium $s p p$. in pre-weaned dairy calves in Northeastern China's Heilongjiang Province. PLoS One. 2013;8:e54857.

4. Bouzid M, Hunter PR, Chalmers RM, Tyler KM. Cryptosporidium pathogenicity and virulence. Clin Microbiol Rev. 2013; 26(1):115134.

5. Stark D, Al-Qassab SE, Barratt JL, Stanley K, Roberts T, Marriott D, Harkness J, Ellis JT. Evaluation of multiplex tandem real-time PCR for detection of Cryptosporidium spp., Entamoeba histolytica, and Giardia intestinalis in clinical stool samples, J Clin Microbiol 2011:49:257-262.

6. Checkley W, White AC, Jaganath D, Arrowood MJ, Chalmers RM, Chen XM, Fayer R. A review of the global burden, novel diagnostics, therapeutics, and vaccine targets for Cryptosporidium. Lancet Infect Dis. 2015; 15:85-94.

7. Abeywardena H, Jex AR, Gasser RB. A perspective on Cryptosporidium and Giardia, with an emphasis on bovines and recent epidemiological findings. Adv Parasitol. 2015;88:243-301.

8. Yap NJ, Koehler AV, Ebner J, Tan TK, Yvonne AL, Lim YA, Gasser RB. Molecular analysis of Cryptosporidium from cattle from five states of Peninsular Malaysia. Mol Cell Probes. 2016;30 (1):39-43.

9. Beaver PC, Jung RC. Animal Agents and Vectors of Human Disease. 5th ed. Lea and Febiger, Philadelphia, 1985, p 249.

10. Paul S, Chandra D, Tewari AK, Banerjee PS, Ray DD, Raina OK, Rao JR. Prevalence of Cryptosporidium andersoni: a molecular epidemiological survey among cattle in India. Vet Parasitol. 2009;161:31-35.

11. Tamura K, Stecher G, Peterson D, Filipski A, Kumar S. MEGA6: Molecular Evolutionary Genetics Analysis version 6.0. Mol Biol Evol. 2013; 30: 2725-2729.

12. Petrie A, Watson P. Statistics for veterinary and animal science. $2^{\text {nd }}$ ed. Ames: Blackwell Publishing; 2006. 24-112 p.

13. Uppal B, Singh O, Chadha S, Jha AK. A Comparison of Nested PCR assay with conventional techniques for diagnosis of intestinal cryptosporidiosis in AIDS Cases from Northern India. J Parasitol Res. 2014;2014:706105

14. Omoruyi BE, Nwodo UU, Udem CS, Okonkwo FO. Comparative diagnostic techniques for Cryptosporidium infection. Molecules. 2014;19:2674-2683. doi: 10. 3390 /molecules 19022674

15. Benhouda D, Hakem A, Sannella AR, Benhouda A, Cacciò SM. First molecular investigation of Cryptosporidium spp. in young calves in Algeria. Parasite. 2017;24:15.

16. Taha S, Elmalik K, Bangoura B, Lendner M, Mossaad E, Daugschies A. Molecular characterization of bovine Cryptosporidium isolated from diarrheic calves in the Sudan. Parasitol Res. 2017;116(11):29712979. doi: 10.1007/s00436-017-5606-8

17. Rzezutka A, Kaupke A. Occurrence and molecular identification of Cryptosporidium spp. isolated from cattle in Poland. Vet Parasitol. 2013;196:301-306.

18. Manyazewal A, Francesca S, Pal M, Gezahegn M, Tesfaye M, Lucy M, Teklu W, Getachew T. Prevalence, risk factors and molecular characterization of Cryptosporidium infection in cattle in Addis Ababa and its environs, Ethiopia. Vet Parasitol Reg Stud Reports. 2018;13:79-84. doi: 10.1016/j.vprsr.2018.03.005.

19. Mohammed ST, Khalaf AA, Fouad H. Detection the genotyping of Cryptosporidium parvum isolated from human and calves and studying in vivo effect of Sacharomyces boulardii on parasite. AlMustansiriyah J Sci. 2016;27(3):6-12.

20. Aouatif O, Belkhiri A, de Lucio A, Köster PC, Djoudi M, Dadda A, Khelef D, Kaidi R, Carmena D. Cryptosporidium-associated diarrhea in neonatal calves in Algeria. Vet Parasitol Reg Stud Reports. 2018;12:78-84.

21. Silverlas C. Cryptosporidium Infection in Dairy Cattle. Prevalence, species distribution and associated management factors $[\mathrm{PhD}$ dissertation]. Swedish: Swedish University of Agricultural Sciences; 2010; p: 33-41.

22. Venu R. Molecular detection and typing of cryptosporidium in dairy calves [PhD dissertation]. Chennai: College tamil nadu veterinary and animal sciences University Chennai; 2010. 600-007 p.

23. Mahfouz ME, Mira N, Amer S. Prevalence and genotyping of Cryptosporidium spp. in farm animals in Egypt. J Vet Med Sci. 2014;76(12):1569-1575. doi: 10.1292/jvms.14-0272

24. Tao W, Li Y, Yang H, Song M, Lu Y, Li W. Widespread occurrence of zoonotic Cryptosporidium spp. and subtypes in dairy cattle from northeast China: Public health concerns. J Parasitol. 2018;104(1):1017.

25. Muhid A, Robertson I, Ng J, Ryan U. Prevalence of and management factors contributing to Cryptosporidium spp. infection in pre-weaned and post-weaned calves in Johor, Malaysia. Exp Parasitol. 2011;127:534-538.

26. Qi MZ, YQ, Fang YQ, Wang XT, Zhang LX, Wang RJ, Du SZ, Guo YX, Jia YQ, Yao L, Liu QD, Zhao GH. Molecular characterization of Cryptosporidium spp. in pre-weaned calves in Shaanxi Province, north-western China. J Medical Microb. 2015;64:111-116.

27. Silva FM, Lopes RS, Araújo-Junior JP. Identification of Cryptosporidium spp. and genotypes in dairy cattle in Brazil. Rev Bras Parasitol Vet. 2013;22(1):1-7.

28. Shrestha RD. Molecular epidemiology of waterborne zoonoses in the north island of New Zealand [PhD dissertation]. New Zealand: Institute of Veterinary, Animal and Biomedical Sciences, Massey University, Palmerston North, New Zealand; 2016; 119p.

29. Hingole AC, Gudewar JG, Pednekar RP, Gatne ML. Prevalence and molecular characterization of Cryptosporidium spp. in cattle and buffalo calves in Mumbai region of India. J Parasit Dis. 2017;41(1):131-136. doi: 10.1007/s12639-016-0763-8

30. Cai M, Guo Y, Pan B, Li N, Wang X, Tang C, Feng Y, Xiao L. Longitudinal monitoring of Cryptosporidium spp. in pre-weaned dairy calves on five farms in Shanghai, China Vet Parasitol. 2017;241:1419.

31. Inpankaew T, Jiyipong T, Sunanta C, Kengradomkij C, Pinyopanuwat $\mathrm{N}$, Jittapalapong S. Prevalence and molecular characterization of 
bovine Cryptosporidium from dairy cows in Northern Thailand. Acta Parasitologica, 2017;62(4):772-774.

32. Ng J, Yang R, McCarthy S, Gordon C, Hijawi N, Ryan U. Molecular characterization of Cryptosporidium and Giardia in pre-weaned calves in Western Australia and New South Wales. Vet Parasitol. 2011;176:145-150.

33. Helmy YA. Epidemiological investigations on the public health significance of Cryptosporidium parasites in livestock and people in the Ismailia Canal Zone of Egypt [PhD dissertation]. Freie Universität Berlin, Germany; 2014. 77 p. doi.org/10.1016/j.vetpar.2012.12.015.

34. Thomson S. Cryptosporidiosis in farm livestock [ $\mathrm{PhD}$ dissertation]. Glasgow: University of Glasgow; 2016; P: 112-117.

35. Ng JS. Molecular epidemiology and metabolomic characterization of Cryptosporidium [PhD dissertation]. Murdoch: Murdoch University; 2017; p: 94. 